\title{
IMPLEMENTASI PRINSIP-PRINSIP MANAJEMEN PENDIDIKAN ISLAM: STUDI KASUS MADRASAH IBTIDAIYAH “AL-MUKMININ” KALANGAN, JOMBANG
}

\author{
Ririn Rosdiarini \\ Kementerian Agama Kabupaten Jombang \\ Email: ririntata@gmail.com
}

\begin{abstract}
Education management, including madrasas, is undergoing a fundamental change, especially in terms of paradigm it develops, i.e. applying bottom up management concepts with a primary focus on efforts to improve quality through autonomy, accountability, accreditation, and evaluation. This new paradigm is basically used to arouse motivation and to launch systems based on merit, transparency, and public accountability. Madrasa, as an Islamic educational institution, in addition to aligning themselves with changes in aspects of the management paradigm as mentioned above also still maintain its characteristics. This characteristic distinguishes between madrasas and general educational institutions. One such distinction is the application of management principles derived from the great sources of Islamic teacbings, namely the Qur'an and Hadith. Using a qualitative approach and descriptive-analytical method, this study describes the application of the principles of Islamic education management by taking the locus of research at MI "Al-Mukminin" Kalangan Perak, Jombang Regency. This study tries to examine the extent to which this institution applies the principles of Islamic education management which includes such principles as shürä, ikhlas, sidq, amanah, and taqwa-. Based on data, which was explored in depth through interviews and observations, the study finds that MI "Al-Mukminin" has properly applied the principles of Islamic education management. In addition, the application of these principles is also in accordance with the vision, mission, and objectives of the madrasa.
\end{abstract}

Keywords: Management, Islamic education.Implementation.

\begin{abstract}
Abstrak
Pengelolaan pendidikan, termasuk madrasah, saat ini mengalami perubahan yang mendasar terutama dalam aspek paradigma yang dikembangkannya, yaitu menerapkan konsep manajemen yang bersifat bottom up dengan fokus utama pada usaha peningkatan mutu melalui otonomi, akuntabilitas, akreditasi dan evaluasi. Paradigma baru ini pada dasarnya dipergunakan untuk menggugah motivasi, melancarkan sistem berdasarkan merit, transparansi dan akuntabilitas publik. Madrasah, sebagai lembaga pendidikan keagamaan Islam, selain menyelaraskan diri dengan perubahan dalam aspek paradigma manajemen sebagaimana disebut di atas juga tetap menjaga ciri khasnya. Ciri khas inilah yang membedakan antara madrasah dan lembaga pendidikan umum. Salah satu distingsi dimaksud adalah diterapkannya prinsip-prinsip manajemen yang diderivasi dari sumber agung ajaran Islam, yaitu al-Qur'an dan Hadis. Menggunakan pendekatan kualitatif serta metode deskriptif-analitis, penelitian ini menguraikan penerapan prinsip-prinsip manajemen pendidikan Islam dengan mengambil lokus penelitian di MI "Al-Mukminin" Kalangan
\end{abstract}


Perak, Kabupaten Jombang. Penelitian ini mencoba mengungkap sejauh mana lembaga tersebut menerapkan prinsip-prinsip manajemen pendidikan Islam yang meliputi prinsip shürä, prinsip ikblas, prinsip sidq, prinsip amāahah, dan prinsip taqwä. Berdasarkan data yang digali secara mendalam melalui wawancara dan observasi, peneliti menyimpulkan bahwa MI "Al-Mukminin" Kalangan telah menerapkan prinsip-prinsip manajemen pendidikan Islam dengan baik. Selain itu, penerapan prinsip-prinsip tersebut juga berkesesuaian dengan visi, misi, dan tujuan madrasah.

Kata kunci: Manajemen, Pendidikan Islam. Implementasi.

\section{PENDAHULUAN}

Artikel ini menjelaskan implementasi prinsip-prinsip manajemen pendidikan Islam yang terkandung di dalam al-Qur'an dan Hadis. Al-Qur'an, sebagai kitab suci bagi umat Islam, sebagaimana dijelaskan oleh para cendekiawan Muslim memuat doktrindoktrin yang nyaris menyentuh semua aspek kehidupan ${ }^{1}$ manusia, termasuk di dalamnya aspek pendidikan. Di sisi lain tidak sedikit pula Hadis (prophetic tradition), sebagai penjelas terhadap al-Qur'an, yang juga menjelaskan tentang pendidikan (Muhammad, 1991).

Pendidikan sendiri merupakan salah satu aspek terpenting dalam kehidupan manusia bahkan sejak dia dilahirkan (Ma`arif, 2017). Peran signifikan yang dimainkan oleh pendidikan bagi manusia memperoleh atensi yang sangat kuat dari kedua sumber utama hukum Islam tersebut.

\footnotetext{
1 Di antara cendekiawan Muslim yang berpendapat bahwa al-Qur'an [meskipun hanya memberi isyarat secara global/bukan penjelasan terperinci] merupakan kitab suci yang komprehensif adalah Syaikh Muhammad al-Ghazāili (maha guru besar di Universitas al-Azhar Mesir).
}

Ayat al-Qur'an dan Hadis Nabi Muhammad yang menjelaskan tentang pendidikan (yang dimaknai baik dalam aspek tarbiyah maupun ta'lïm) menegaskan bahwa aspek ini tidak boleh diabaikan. Hal ini karena pendidikan dan pengajaran (yang di dalam keduanya terdapat ilmu pengetahuan) merupakan salah satu instrumen penting yang mampu mengantarkan manusia mencapai derajat mulia (Abdullah \& Syahri, 2019; Ridwan, 2018; Rosyad \& Maarif, 2020).

Dalam perkembangannya, ketika pendidikan berada dalam konstelasi dunia modern unsur-unsurnya mengalami beragam inovasi evolutif. Salah satu unsur terpenting dalam dunia pendidikan modern yang mengalami perkembangan dinamis adalah manajemen. Dalam konteks ini, pendidikan dikatakan baik jika ia memenuhi kriteriakriteria manajemen. Manajemen yang dimaksud di sini adalah suatu manajemen yang, tentunya, memiliki relevansi dengan pendidikan itu sendiri (Maarif \& Rofiq, 2018). 
Pada prinsipnya, manajemen pendidikan adalah implementasi prinsipprinsip manajemen dalam ranah pendidikan. Mengutip pendapat Gerald N. Kimani, Priadi Surya menjelaskan bahwa manajemen pendidikan merupakan suatu ranah terapan (applied field) dari manajemen itu sendiri (Surya, 2011). Dengan demikian, dapat ditarik suatu kesimpulan bahwa manajemen pendidikan merujuk kepada suatu aplikasi manajemen baik teori maupun praktik ke dalam dunia pendidikan dan institusi pendidikan. Hal ini meniscayakan sebuah proses pencapaian dan, pada saat yang sama, pengalokasian sumber daya bagi tercapainya tujuan-tujuan pendidikan yang telah ditentukan.

Menggunakan pendekatan kualitatif dengan metode deskriptif-analitis, artikel ini menjelaskan implementasi prinsip-prinsip manajemen pendidikan Islam dalam dunia pendidikan Islam. Untuk keperluan tersebut studi ini mengambil kasus di Madrasah Ibtidaiyah (MI) "Al-Mukminin" Kalangan, Desa Kalangsemanding, Kecamatan Perak, Kabupaten Jombang. Kajian ini bertujuan menggugah kembali kesadaran para pendidik (guru) di lembaga pendidikan tersebut untuk mengimplementasikan prinsip-prinsip manajemen pendidikan Islam yang dilandasi nilai-nilai al-Qur'an dan Hadis guna mencapai tujuan pendidikan di lembaga tersebut.

\section{Visi, Misi, dan Tujuan MI "Al- Mukminin" Kalangan}

Berikut ini diuraikan secara singkat visi, misi, dan tujuan MI "Al-Mukminin" Kalangan. Adapun misi madrasah tersebut adalah: "Bertakwa, unggul dalam prestasi, kompetitif dan berbudi pekerti islami" (Dokumen Rencana Kerja Madrasah (RKM) 4 Tabun (2017-2021) MI "Al-Mukminin" Kalangan Perak Jombang., 2018). Dalam mewujudkan misi tersebut ditetapkan beberapa indikator, yaitu:

1) Unggul dalam aktivitas keagamaan;

2) Unggul dalam prestasi akademik;

3) Unggul dalam kegiatan olahraga;

4) Unggul dalam bidang kesenian;

5) Unggul dalam bidang kepramukaan.

Guna melengkapi misi di atas, MI "Al-Mukminin" menetapkan misi madrasah yang terdiri dari(Dokumen Rencana Kerja Madrasah (RKM) 4 Tabun (2017-2021) MI "Al-Mukminin" Kalangan Perak Jombang., 2018):

1. Meningkatkan pembelajaran secara efektif dan terpadu antara aspek rubiyah (afektif), 'aqliyah (kognitif) dan jismiyah (psikomotorik) sehingga siswa dapat berkembang secara optimal sesuai dengan prestasi yang dimilikinya. 
2. Menumbuhkan pembinaan dan penghayatan terhadap ajaran agama sehingga menjadi sumber kedisiplinan dan kearifan dalam bertindak.

3. Mengembangkan bakat siswa dalam bidang olahraga.

4. Menampilkan siswa yang berbudaya dan berkreasi seni tinggi.

5. Menumbuhkan jiwa kreatif, kepimimpinan serta kemandirian siswa.

Selain visi dan misi, MI "AlMukminin" Kalangan juga memiliki tujuan yang dibatasi secara khusus dalam empat tahun. Adapun tujuan MI "Al-Mukminin" dalam empat tahun ke depan adalah:

1. Menciptakan karakter pada diri peseta didik yang mampu dengan baik dan benar serta istiqamah mengamalkan ajaran agama, hasil proses pembelajaran, dan kegiatan pembiasaan.

2. Mampu mempertahankan prestasi akademik maupun non-akademik minimal di tingkat Kecamatan Perak.

3. Dengan matang menguasai dasar-dasar ilmu pengetahuan dan teknologi sebagai bekal untuk melanjutkan ke tingkat pendidikan yang lebih tinggi.

4. Memiliki kepedulian dan kesadaran warga Madrasah terhadap keamanan, kebersihan dan keindahan lingkungan Madrasah daripada sebelumnya.
5. Semakin meningkat baik secara kualitas maupun kuantitas sarana/ prasarana dan fasilitas yang mendukung peningkatan prestasi akademik dan non-akademik.

6. Menciptakan peningkatan indikator nilai lulusan (out put) yang berkualitas dan handal dari tahun ke tahun dan siap bersaing dengan lulusan lainnya.

7. Pada tahun 2018, para siswa yang memiliki minat, bakat dan kemampuan terhadap Bahasa Arab dan Inggris semakin meningkat dari sebelumnya, dan mampu menjadi MC dan berpidato dengan 2 bahasa tersebut.

8. Pada tahun 2020, akan memiliki tim kesenian yang mampu tampil sebagai juara 1 minimal pada Porseni tingkat Kabupaten dan/atau Provinsi.

9. Pada tahun 2020 terjadi peningkatan manajemen partisipatif warga Madrasah, diterapkanya manajemen pengendalian mutu Madrasah, terjadi peningkatan animo siswa baru, dan akreditasi Madrasah mendapatkan nilai "A".

\section{Prinsip-prinsip Manajemen dalam} Perspektif Islam dan Korelasinya dengan Manajemen Pendidikan Islam

Pendidikan Islam, bersama dengan beragam unsur di dalamnya, selalu menjadi wilayah kajian menarik untuk didiskusikan. 
Hal ini karena pendidikan Islam, sampai pada batas tertentu, berada dalam titik pusat pergumulan artikulasi identitas "keberislaman" seorang muslim. Argumentasinya adalah bahwa melalui institusi-institusi pendidikan Islam, seorang muslim bisa membicarakan aspek-aspek authentic self (kedirian otentik) dalam perspektif keagamaan, terutama Islam (Masdar Hilmy dalam Mukani, 2015, p. 292). Dengan demikian dapat dipahami bahwa pendidikan Islam serta institusi pendidikan Islam menjadi wadah yang memungkinkan siapapun yang berkecimpung di dalamnya untuk menjadi bagian dari komunitas akademik global, namun pada saat yang sama masih mempertahankan dan mengedepankan otentisitas dan originalitas nilai-nilai keislaman.

Otentisitas dan originalitas dimaksud di atas tidak dimaknai bahwa pendidikan Islam bersikap skeptis dan menolak unsurunsur yang berasal dari luar. Selama unsurunsur eksternal tersebut berkesesuaian (compatible) dengan nilai-nilai Islam, maka pada titik itulah mereka bisa diterima dan, bahkan, diimplementasikan dalam ranah pendidikan Islam. Hal ini meniscayakan para agen dalam dunia pendidikan Islam memiliki sikap yang selektif-adaptif di satu sisi dan kritis-solutif di sisi lain.
Membincang otentisitas dan originalitas dan kaitannya dengan manajemen pendidikan, dunia pendidikan Islam sesungguhnya memiliki prinsip-prinsip manajemennya sendiri. Prinsip-prinsip manajemen pendidikan Islam ini memiliki basis ontologis, aksiologis, dan epistemologis yang kuat. Hal ini karena prinsip-prinsip tersebut diadopsi langsung dari kitab suci alQur'an. Pernyataan ini tentu sedikitpun tidak berpretensi mengecilkan dan menafikan prinsip-prinsip manajemen pendidikan modern-sekular atau membuat dikotomi antara aspek pendidikan keagamaan dan umum. Penggunaan prinsip-prinsip manajemen pendidikan Islam dalam kajian ini semata-mata karena lokus studi kasus yang diangkat dalam artikel ini adalah lembaga pendidikan Islam, sehingga menurut hemat penulis pisau analisa yang digunakan haruslah memiliki kesesuaian dengan tujuan dimaksud dalam studi ini.

Menurut Alhammi dalam bukunya The Fact of Consultation in Islam, sebagaimana dikutip oleh Alkrdem dan Alqahtani, dijelaskan bahwa manajemen adalah hal yang berkaitan dengan pelayanan terhadap orang lain serta aspek-aspek yang menyertainya seperti perencanaan (planning), pengaturan (organizing), bimbingan (guidance), dan penyajian (presentation). Dengan demikian, 
manajemen meniscayakan adanya tanggung jawab, keyakinan serta loyalitas dalam setiap tindakan dengan tujuan memberikan pelayanan terbaik bagi orang lain dan di saat yang sama memenuhi kebutuhan-kebutuhan mereka. Dengan kata lain, tanggung jawab, keyakinan, loyalitas, dan pelayanan terbaik terhadap orang merupakan nilai-nilai yang seharusnya dijunjung tinggi dalam manajemen pendidikan Islam (Kartiko \& Azzukhrufi, 2019).

Pertanyaan yang mungkin diajukan adalah bagaimana jika konsep manajemen tersebut dikomparasikan dengan konsep manajemen modern-sekular (baca: Barat)? Alkrdem dan Alqahtani dengan tegas menambahkan bahwa konsep manajemen dunia Barat hanya terbatas pada usaha mewujudkan tujuan tertentu berlandaskan hal-hal yang sifatnya material (Alkrdem \& Alqahtani, 2016). Hal ini sebenarnya bukanlah sesuatu yang mengherankan, mengingat dunia Barat sangat dipengaruhi oleh materialisme dalam banyak aspek kehidupannya. Meskipun demikian, sekali lagi penulis menegaskan bahwa manajemen ala Barat tetap memiliki urgensitas pada titik dan batas tertentu. Artinya, ia tidak pula harus ditolak. Menurut hemat penulis, terdapat aspek-aspek yang tetap relevan dalam manajemen dunia Barat serta kompatibel untuk diterapkan dalam manajemen pendidikan Islam.

Di sisi lain, masih menurut Alkrdem dan Alqahtani, tujuan manajemen dalam perspektif Islam adalah untuk memberikan pelayanan kepada orang lain. Artinya, memprioritaskan kepentingan publik di atas kepentingan pribadi-perorangan maupun kelompok serta memfokuskan perhatian terhadap aspek-aspek spiritual dan psikologis di atas aspek-aspek fisik menjadi hal yang tidak bisa diabaikan dalam manajemen dalam perspektif Islam (Alkrdem \& Alqahtani, 2016). Manajemen dalam perpsektif Islam, dengan demikian, menyeimbangkan antara pemenuhan aspek-aspek yang bersifat material dan spiritual. Keseimbangan antara kedua aspek tersebut menjadi penting karena sesungguhnya tujuan dari manajemen dalam pandangan Islam tidak hanya terbatas berorientasi pada hubungan dengan sesama manusia (aspek horizontal atau habl min alnas) melainkan juga berkaitan dengan hubungan manusia dengan Tuhannya (aspek vertikal atau habl min Allab).

Prinsip-prinsip manajemen pendidikan Islam sendiri telah digariskan dalam al-Qur'an dan Sunnah. Alkrdem dan Alqahtani menjelaskan bahwa prinsip-prinsip manajemen pendidikan dalam perspektif Islam terdiri dari: pertama, prinsip shura. (Alkrdem \& Alqahtani, 2016). Prinsip ini 
ditemukan dalam surah al-Shura [42] ayat 38 (Al-Qur`an, 2010). ${ }^{2}$ Prinsip shura sendiri dapat dimaknai dengan "konsultasi dan partisipasi". Pemimpin Muslim yang hebat bukanlah orang yang mampu bekerja sendiri ataupun menyelesaikan permasalahan dalam lingkungan kerjanya seorang diri tanpa melibatkan orang-orang yang berada di bawahnya. Pemimpin yang baik adalah dia yang justru mampu bekerja secara tim (team work) dengan melibatkan seluruh potensi sumber daya, khususnya sumber daya manusia melalui mekanisme konsultasi.

Hal ini karena manajemen dalam pandangan Islam tidak mengenal istilah autoritarianisme yang menjadikan seorang pemimpin memiliki wewenang absolut dalam mengambil suatu keputusan dan kebijakan dengan mengesampingkan pendapat orang lain. Sebaliknya, manajemen dalam perspektif Islam, termasuk manajemen pendidikan, sangat menekankan pentingnya partisipasi seluruh komponen yang ada dalam suatu tim manajemen, baik pemimpin maupun orang-orang yang ada di level bawah.

\footnotetext{
2 Arti ayat tersebut: "Dan (bagi) orang-orang yang menerima (mematuhi) seruan Tuhannya dan mendirikan shalat, sedang urusan mereka (diputuskan) dengan musyawarah antara mereka; dan mereka menafkahkan sebagian dari rezeki yang Kami berikan kepada mereka."
}

Prinsip shura yang diterapkan dengan baik dalam suatu manajemen, termasuk manajemen pendidikan Islam, juga memiliki implikasi positif di mana salah satunya adalah terwujudnya kesamaan (equality) dan keadilan (justice); yang akan diuraikan di bawah sebagai bagian dari prinsip manajemen dalam Islam. Menjadi sebuah keharusan bagi seorang kepala sekolah, misalnya, untuk selalu mengedepankan prinsip ini dalam setiap pengambilan keputusan dan penentuan kebijakan terkait dengan kepentingan dan kemajuan sekolah. Terlibatnya semua guru secara langsung juga bisa menciptakan suatu kondisi psikologis yang positif di mana setiap individu merasa diperlakukan dengan sama dan adil. Hal ini pada gilirannya mampu menumbuhkan iklim manajemen pendidikan di sekolah yang sehat dan harmonis.

Kedua, prinsip ikblas (Alkrdem \& Alqahtani, 2016). Prinsip ini dapat dimaknai dengan ketulusan dan integritas. Manajemen islami menilai bahwa ketulusan disertai integritas sebagai prinsip yang sangat penting. Prinsip ini terkait erat dengan, antara lain, ayat 1 surah al-Mā'idah [5](AlQur`an, 2010). ${ }^{3}$ Ayat ini menegaskan bahwa

\footnotetext{
3 Arti ayat tersebut: "Hai orang-orang yang beriman! Penuhilah janji-janji." Janji di sini adalah janji setia hamba kepada Allah dan perjanjian yang dibuat oleh manusia dalam konteks relasi dan pergaulan dengan sesamanya.
} 
seseorang diharuskan memenuhi kewajibankewajiban moralnya disertai dengan sikap yang tulus dan pada saat yang sama menjaga serta menepati janji-janjinya.

Prinsip ketulusan jika dikaitkan dengan manajemen pendidikan Islam mampu menumbuhkembangkan budaya kepercayaan (trust), kejujuran (truthfulness) ${ }^{4}$, kepercayaan diri (confidence), dan kerja sama (cooperation) di antara pimpinan suatu lembaga pendidikan Islam dan orang-orang di bawahnya. Hal ini, menurut hemat penulis, cukup beralasan karena seorang pemimpin yang melandasi kepemimpinannya dengan prinsip ketulusan dan integritas akan memiliki kewibawaan. Dengan demikian, akan timbul perasaan segan (bukan takut) di level bawah dan ini menjadi energi positif bagi mereka untuk bertindak yang sama dengan pimpinannya. Kesamaan tindakan ini pada akhirnya menjadi titik temu di mana semua komponen akan saling mempercayai, berlaku jujur, memiliki kepercayaan diri, dan bersedia bekerjasama dalam memajukan institusi pendidikan.

Ketiga, prinsip sidq. Prinsip ini diartikan dengan "kejujuran". Kejujuran di sini dimaknai dengan keselarasan antara pikiran, perkataan, dan perbuatan baik yang

\footnotetext{
${ }^{4}$ Kepercayaan (trust) dan kejujuran (truthfulness) juga menjadi prinsip dalam manajemen dalam perspektif Islam dan akan diuraikan di bawah.
}

sesuai dengan standar norma agama dan sosial. Dalam khazanah etika islami, kejujuran memiliki lawan, yaitu dusta atau kebohongan (kidhb). Allah SWT bahkan melaknat para pembohong. Hal ini sebagaimana firman-Nya dalam bagian akhir ayat 61 surah Ali 'Imran [3]. Selain itu Nabi Muhammad SAW memberikan atensi yang sangat spesial terhadap dua sifat yang berlawanan tersebut. Tidak sedikit Hadis Nabi yang memerintahkan manusia untuk memegang teguh nilai kejujuran dan menjauhi kebohongan (Ahmad, 1994). Shams al-Din al-Dhahabiy dalam karyanya Al-Kaba'ir bahkan menggolongkan dusta sebagai salah satu dosa besar (Syamsuddin, 1994).

Merupakan sebuah kewajiban bagi lembaga pendidikan, tidak terkecuali lembaga pendidikan Islam [setelah keluarga], menjadi tempat persemaian dan penanaman kejujuran dalam diri setiap peserta didik. Itu semua hanya bisa dilakukan apabila pimpinan serta semua guru dalam lembaga tersebut juga memiliki sifat jujur. Manajemen pendidikan bisa efektif hanya apabila ia dilandasi oleh nilai kejujuran. Dengan kata lain, kejujuran merupakan pusat terciptanya manajemen yang efektif. Karena kejujuran pula sumber daya material yang ada tidak

\footnotetext{
5 Arti ayat tersebut: "... (dan kita minta) agar laknat Allah ditimpakan kepada orang-orang yang dusta."
} 
akan disalahgunakan untuk kepentingan pribadi. Selanjutnya, karena kejujuran juga setiap individu yang terlibat dalam manajemen akan melakukan tugas-tugasnya dengan penuh tanggung jawab.

$$
\text { Keempat, prinsip amanah }
$$
(kepercayaan). Prinsip ini sesuai dengan ayat 27 surah al-Anfāl [8]. ${ }^{6}$ Dapat disimpulkan dari ayat tersebut bahwa khiyānah adalah lawan dari amānah. Hal ini karena ayat tersebut secara eksplisit memang melarang manusia mengkhianati kepercayaan yang diberikan kepada mereka. Dalam konteks relasi sosial-kemasyarakatan, kejujuran juga merupakan hal terpenting, bahkan ia merupakan nilai paling utama (core value) bagi berjalannya hubungan sosial. Tanpa dilandasi nilai kepercayaan, hubungan antarmanusia hanya akan dipenuhi dengan prasangka (prejudice). Jika hal ini terjadi maka tatanan sosial (social order) pun akan terdegradasi.

Dalam konteks manajemen, Alkrdem dan Alqahtani -- mengutip pendapat Brooks (2015) dalam artikelnya yang berjudul "School Principals in Southern Thailand: Exploring Trust with Community Leaders During Conflict" yang dimuat dalam jurnal Educational Management Administration \&

\footnotetext{
6 Arti ayat tersebut: "Hai orang-orang yang beriman, janganlab kamu mengkbianati Allab dan Rasul (Muhammad) dan (juga) janganlah kamu mengkhianati amanat-amanat yang dipercayakan kepadamu, sedang kamu mengetahui."
}

Leadership-- menegaskan bahwa dengan adanya kepercayaan, disertai konsultasi, maka pendelegasian wewenang dapat terwujud dan mencapai tujuan yang diharapkan. Lebih jauh, masih menurut Brooks, kepercayaan juga menciptakan iklim organisasi yang baik dalam suatu lembaga (Alkrdem \& Alqahtani, 2016).

Apabila kepercayaan diterapkan dalam ranah manajemen pendidikan Islam, tentu prinsip ini akan memiliki dampak positif bagi kemajuan suatu lembaga pendidikan Islam. Kepercayaan yang diberikan oleh stake bolder, termasuk masyarakat misalnya, kepada lembaga pendidikan Islam akan berbanding lurus dengan keberlangsungan lembaga itu sendiri. Hal ini karena masyarakat melihat bahwa lembaga tersebut dikelola dengan manajemen yang baik dan akuntabel. Sebaliknya, jika prinsip kepercayaan diabaikan dalam manajemen suatu lembaga pendidikan, maka masyarakat juga akan kehilangan kepercayaan terhadap lembaga tersebut.

Kelima, prinsip taqwa (takut kepada Allah) (Alkrdem \& Alqahtani, 2016). Prinsip inilah yang membedakan antara manajemen islami dan manajemen ala Barat. Sebagaimana telah disinggung di atas, jika manajemen dalam pandangan Barat hanya 
berorientasi pada aspek material-horizontal, manajemen dalam perspektif Islam selain memperhatikan aspek tersebut juga menekankan aspek spiritual-vertikal, dan hal ini termanifestasi dalam taqwā Allah. Dengan kata lain, takut kepada Allah merupakan titik kulminasi penerapan manajemen dalam perspektif Islam.

Takwa kepada Tuhan bahkan merupakan tujuan tertinggi dari setiap perbuatan manusia. Ayat-ayat yang berisi perintah takwa pun ditemukan sangat banyak dalam al-Qur'an. Al-Qur'an sendiri telah dideklarasikan oleh Allah SW'T sebagai petunjuk bagi orang-orang yang bertakwa (hudā li al-muttaqīn), sebagaimana tercantum dalam ayat 2 surah al-Baqarah [2]. Ketika hati seseorang dipenuhi ketakutan kepada Allah SWT, dia akan melakukan perbuatan-perbuatan terpuji dan menghindari tindakan-tindakan tercela. Prinsip ini menjadi semacam alat introspeksi diri (self-accountable) sekaligus pengawasan dan penyeimbang (check and balance) yang mampu membingkai karakteristik seseorang dalam melaksanakan tugas yang diembankan kepadanya secara jujur dan bertanggungjawab.
Implementasi

Prinsip-prinsip

Manajemen Pendidikan Islam di MI “AlMukminin" Kalangan

Sebagaimana telah dijelaskan di atas bahwa di antara ayat-ayat al-Qur'an dan Hadis Rasulullah mengandung dogmadogma yang berisi prinsip-prinsip manajemen pendidikan Islam. Dalam artikel ini penulis merujuk kepada pendapat Alkrdem dan Alqahtani yang menjelaskan bahwa paling tidak ada lima prinsip manajemen pendidikan dalam perspektif Islam sebagaimana tercantum dalam alQur'an dan Hadis, yaitu prinsip shürā, prinsip ikhlās, prinsip șidq, prinsip amānah, dan prinsip taqwā. Penulis akan mencoba mengelaborasi lima prinsip tersebut dengan data yang penulis temukan baik melalui wawancara maupun observasi di lokus penelitian ini yaitu MI "Al-Mukminin" Dusun Kalangan Jombang. Dalam konteks ini penulis membatasi pembahasan pada sejauh mana kelima prinsip di atas terimplementasi dalam manajemen madrasah tersebut.

Pembahasan pertama adalah implementasi prinsip shūrā. Prinsip shūrā terkait erat dengan konsultasi dan partisipasi, atau dalam istilah lain musyawarah. Penulis menemukan bahwa, sejauh pengamatan penulis, prinsip shürā telah 
diimpelementasikan dengan baik oleh seluruh lini yang ada dan terlibat dalam MI “Al-Mukminin” Kalangan. Sebagai madrasah yang pengelolaannya di bawah naungan Yayasan Al-Mukminin, garis manajerial madrasah ini memang secara otomatis di bawah Ketua Yayasan sebagai leading management. Meski demikian, dalam konteks pengelolaan madrasah, pihak yayasan memberikan wewenang kepada organ-organ manajemen di madrasah, yang terdiri dari kepala madrasah, wakil kepala madrasah, dan seluruh guru, untuk mengelola madrasah tersebut agar mencapai visi, misi, dan tujuan yang telah ditentukan.

Kepala madrasah sebagai organ tertinggi dalam manajemen MI "AlMukminin" selalu mengedepankan prinsip musyawarah dalam setiap penentuan kebijakan terkait kemajuan madrasah. Sebagai contoh, sekali dalam satu bulan kepala madrasah beserta seluruh guru dan perwakilan komite madrasah mengadakan pertemuan rutin. Pertemuan tersebut selain diisi dengan kegiatan keagamaan, khususnya istighathah, juga bertujuan untuk melakukan sharing dan hearing pendapat terkait pengelolaan MI "Al-Mukminin". (Muflihatun Niswah 2019), Wakil Kepala MI “Al-Mukminin”, mengatakan:

Menurut saya, musyawarah merupakan hal penting dalam suatu organisasi apa pun bentuknya. Musyawarah memiliki peranan penting dalam manajemen organisasi, karena dengan musyawarah hal-hal penting seperti kebijakan yang terkait dengan kemajuan organinsasi dibahas, disepakati dan diputuskan oleh semua pihak yang terlibat. Dalam hal ini MI "Al-Mukminin" sebagai sebuah institusi pendidikan Islam tingkat dasar dikelola dengan manajemen yang juga mengedepankan musyawarah. Semua kebijakan yang berhubungan dengan pengelolaan madrasah ini selalu diputuskan melalui forum musyawarah yang melibatkan seluruh pihak terkait, mulai dari Ketua Yayasan Al-Mukminin sampai wali murid. Meski demikian, memang harus diakui bahwa ada beberapa hal terkait kebijakan yang diputuskan melalui musyawarah terbatas yang diikuti hanya oleh beberapa organ penting dalam madrasah. Artinya, tidak selalu melibatkan semua pihak termasuk wali murid.

Niswah (2019) juga menambahkan bahwa pemimpin yang hebat bukanlah orang yang mampu menangani permasalahan dalam lingkungan kerjanya seorang diri dengan mengesampingkan peran orangorang yang berada di bawahnya. Sebaliknya, seorang pemimpin seharusnya mampu bekerja secara kolektif dengan semua pihak dalam organisasi yang dia pimpin. Kerja kolektif (team work) melalui mekanisme musyawarah dan konsultasi dengan melibatkan seluruh potensi sumber daya, 
terutama sumber daya manusia, seharusnya menjadi prioritas utama seorang pemimpin.

Senada dengan pendapat Niswah, Afifah Roziah, salah seorang staf pengajar sekaligus wali murid di MI "Al-Mukminin", juga menjelaskan bahwa prinsip shūrā sangat diutamakan dalam manajemen madrasah tersebut.

Selama menjadi guru di madrasah ini kurang lebih 7 (tujuh) tahun, saya sering dilibatkan dalam musyawarahmusyawarah yang membahas kemajuan madrasah. Sebagai contoh, saya terlibat dalam menentukan kegiatan ekstra-kurikuler apa saja yang diberikan kepada para siswa di mana kegiatan-kegiatan tersebut menjadi unggulan MI "AlMukminin". Bahkan forum musyawarah tersebut pada akhirnya memberikan amanah kepada saya untuk membina salah satu kegiatan ekstra-kurikuler, yaitu tartil al-Qur'an dan tahfidz al-Qur'an juz 30 bagi siwa kelas V dan VI.

Berdasarkan pemaparan dua informan di atas, penulis menyimpulkan bahwa prinsip shürā telah terimplementasi dengan baik dalam manajemen keorganisasian MI "Al-Mukminin" Kalangan. Pihak leading management dalam institusi pendidikan ini sangat menyadari pentingnya mengimplementasikan prinsip shürā dalam penentuan setiap kebijakan

7 Afifah Roziah, Wawancara, Jombang, 20 Januari 2019. yang mengarah pada kemajuan institusi tersebut.

$$
\text { Prinsip kedua yang }
$$
diimplementasikan dalam pengelolaan MI "Al-Mukminin" adalah ikhlās $\}$. Dalam konteks ini, keikhlasan yang diterapkan dalam manajemen pendidikan di MI "AlMukminin" memiliki dua makna, yaitu integritas dan ketulusan. Makna pertama terimplementasi dalam kinerja pengelola madrasah tersebut yang mengedepankan mutu dalam pelayanan khususnya terhadap para peserta didik dan orang tua mereka. Hal ini karena peserta didik dan orang tua merupakan main costumer yang secara langsung merasakan pelayanan dimaksud. Terkait hal ini Muslih Bashori (2019), Ketua Yayasan Al-Mukminin, menegaskan:

Bagaimanapun pelayanan terbaik adalah salah satu prioritas utama yang diberikan oleh pihak manajemen MI "Al-Mukminin" yang bernaung di bawah Yayasan AlMukminin. Terutama pelayanan bagi peserta didik dan wali murid. Karena tanpa mereka sesungguhnya institusi ini bukanlah apa-apa, artinya tidak aka nada dan bertahan hingga saat ini. Oleh karenanya, kami dari pihak yayasan selalu menegaskan kepada manajemen madrasah untuk memberikan pelayanan terbaik dan berintegritas. Selain kami juga selalu mengawasi bagaimana madrasah ini dokelola dengan manajemen yang baik. 


\begin{abstract}
Penjelasan Ketua Yayasan Al-
Mukminin di atas cukup menjadi bukti bahwa manajemen MI “Al-Muknin" telah berusaha semaksimal mungkin menerapkan prinsip ihklāṣ yang berorientasi pada integritas. Adapun ihklāṣ dalam arti ketulusan tergambar, misalnya, dari penjelasan berikut ini:
\end{abstract}

Saya diberi amanah menjadi tenaga pendidik di MI "Al-Mukminin" ini sudah selama tujuh tahun. Sebelum di madrasah ini saya dulu pernah diberi amanah untuk menjadi tenaga pendidik di RA “Al-Mukminin” yang juga berada di bawah naungan Yayasan Al-Mukminin. Tapi karena saya merasa kurang pas, terutama dengan kemampuan saya, saya hanya bertahan satu tahun dan kemudian mengundurkan diri dari RA tersebut. Akhirnya, saya diminta oleh pihak yayasan untuk mengajar di tingkat MI, dan alhamdulillah bertahan sampai sekarang. Prinsip yang saya pegang adalah bahwa menjadi tenaga pendidik di madrasah ini merupakan pengabdian dan kehormatan. Dengan demikian, saya juga tidak mempermasalahkan jumlah reward yang saya terima. Berapapun saya terima dengan ikhlas. Istilahnya nrimo ing pandum. Saya tidak pernah menuntut. Karena yayasan ini bagi saya merupakan amanah yang ditinggalkan oleh pendirinya yang juga kebetulan adalah kakek kandung saya, yaitu Kiai Mukminin. Dan memang pada kenyataannya sebagian SDM yang terlibat dalam pengelolaan yayasan ini adalah keluarga saya. Jadi, bagi saya ini adalah kehormatan dalam rangka melanjutkan perjuangan para perintis
Yayasan Al-Mukminin. . (Roziah 2019)

Penulis menyimpulkan bahwa penjelasan salah satu tenaga pendidik MI "Al-Mukminin" tersebut mengisyaratkan bahwa meskipun di satu sisi manajemen madrasah harus dikelola dengan landasan integritas untuk memberikan pelayanan terbaik kepada para pengguna (users), tapi ketulusan hati pengelolanya juga menjadi bagian penting dalam manajemen tersebut. Meski demikian, kesimpulan penulis ini tidak berpretensi untuk melakukan generalisasi terhadap semua tenaga pendidik yang ada di madrasah tersebut apakah setiap individu memiliki pandangan yang sama dengan informan yang telah penulis wawancarai di $\operatorname{atas}^{8}$

Prinsip ketiga yang diterapkan dalam manajemen MI "Al-Mukminin" adalah șidq (kejujuran). Kejujuran di sini, sebagaimana telah diuraikan di atas, diartikan dengan adanya keselarasan antara pikiran, perkataan,

8 Dalam konteks "ketulusan" ini penulis tidak mewawancarai semua tenaga pendidik di MI "AlMukminin" dengan alasan bahwa pembicaraan terkait pendapatan/penghasilan adalah hal subjektif sekaligus sensitif. Dengan demikian, penulis memilih secara acak informan yang diwawancarai terkait hal ini. Faktanya, informan yang telah penulis wawancarai, yaitu Afifah Roziah, juga tidak bersedia menjelaskan secara eksplisit berapa nominal penghasilan per-bulan yang dia dapatkan sebagai tenaga pendidik di MI " $\mathrm{Al}$ Mukminin". Di bagian akhir wawancara, dia hanya mengatakan: "Alhamdulillah, cukup lah bu untuk membantu keuangan keluarga. Untuk uang jajan anak." 
dan perbuatan baik dengan standar norma agama dan sosial. Implementasi dari prinsip kejujuran tercermin dari penjelasan berikut ini.

Saya dipercaya menjadi bendahara MI “Al-Mukminin”. Semua sirkulasi keuangan di madrasah ini, baik uang masuk dan uang keluar menjadi tanggung jawab saya. Selain ini adalah amanah, bagi saya menjadi bendahara juga merupakan ujian yang berat. Saya selalu dituntut untuk melaporkan keuangan madrasah dengan jujur. Sekecil apapun jumlah uang yang masuk atau keluar harus dilaporkan secara terbuka. Kalau istilah sekarang akuntabel.

Hasil wawancara dengan Muhayaroh di atas memberi ilustrasi bahwa kejujuran merupakan bagian penting dari manajamen MI “Al-Mukminin”. Sebagaimana dimaklumi bahwa salah satu aspek penting bertahannya sebuah lembaga pendidikan adalah keuangan yang sehat. Hal ini karena tidak bisa dipungkiri bahwa lembaga pendidikan memerlukan alokasi dana guna menunjang operasional, misalnya pengadaan sarana dan prasarana guna menunjang kemajuan lembaga itu sendiri. Oleh karena itu, menurut hemat penulis, keuangan suatu lembaga pendidikan sudah seharusnya dikelola secara baik dan akuntabel dengan mengedepankan kejujuran dan hal ini juga meniscayakan adanya SDM yang jujur yang mampu mengelola keuangan tersebut.
Sebenarnya implementasi prinsip kejujuran dalam manajemen $\mathrm{MI}$ "AlMukminin" tidak hanya terbatas pada urusan keuangan saja. Sebagai lembaga pendidikan Islam, prinsip ini secara implisit juga tercermin dalam visi dan misi lembaga tersebut yang menanamkan akhlak mulia kepada peserta didiknya. Secara normatif, kejujuran adalah salah satu bagian dari akhlak mulia dimaksud. Menurut Muflihatun Niswah, aspek kejujuran menjadi salah satu nilai utama yang ditanamkan dalam diri seluruh "keluarga besar" MI Al-Mukminin:

Dalam misi dan misi madrasah ini tercermin bagaimana lembaga ini sebagai lembaga pendidikan islami menekankan pentingnya penanaman budi pekerti islami dan akhlak mulia dalam diri setiap peserta didik. Dan di antara akhlak mulia tersebut adalah kejujuran. Dalam hal ini guru sebagai pendidik selalu menekankan pentingnya nilai tersebut. Sebagai contoh, terjadi beberapa kali kasus siswa yang kehilangan uang. Setelah dilakukan investigasi mendalam pada akhirnya diketahui adanya oknum siswa yang melakukan tindakan pencurian tersebut. Lalu kami lakukan interogasi dan siswa yang bersangkutan mengakui perbuatannya. Kami selaku pendidik tentu hanya bisa berpesan kepada siswa tersebut untuk tidak mengulangi perbuatannya. Selanjutnya, kami juga melaporkan tindakan pencurian tersebut 
kepada orang tua si peserta didik. Kami juga meminta bantuan kepada orang tua agar ikut mendidik anak tersebut dengan baik, secara arif dan bijaksana tanpa perlu melakukan kekerasan dalam proses pendidikannya.

Dalam konteks penjelasan di atas, menjadi kewajiban bagi lembaga pendidikan Islam bersama orang tua untuk senantiasa menyemai dan menanamkan nilai kejujuran dalam diri setiap anak. Tentu, hal tersebut hanya bisa dilakukan jika guru dan orang tua juga memberikan contoh nyata dalam berperilaku jujur. Kejujuran juga memiliki dampak positif dalam efektivitas suatu manajemen pendidikan. Dengan kata lain, jika sebuah lembaga pendidikan Islam menghendaki terwujudnya manajemen yang efektif tanpa adanya penyalahgunaan sumber daya, maka ia harus menjadikan kejujuran sebagai pusat setiap perilaku manajerial.

Amānah (kepercayaan) sebagai prinsip keempat juga menjadi pondasi manajemen pendidikan Islam di MI "AlMukminin". Dalam konteks ini, trust menjadi aspek penting yang melandasi relasi antarmanusia. Tanpa adanya rasa saling percaya, hubungan hanya akan dipenuhi dengan prasangka (prejudice). Jika hal ini terjadi maka tatanan sosial (social order) pun akan terdegradasi. Sumali, salah seorang guru senior di MI “Al-Mukminin” menegaskan:
Sejak kurang lebih 20 tahun saya mengabdi menjadi tenaga pendidik di madrasah ini, saya telah menjadi bagian dari saksi sejarah bagaimana MI Al-Mukminin mengalami pasang surut. Secara informal, saya secara pribadi diberi kepercayaan oleh Pengurus Yayasan Al-Mukminin untuk meng-handle hal-hal yang berkaitan dengan hubungan kemasyarakatan. Salah satu hal penting dalam tugas saya tersebut adalah menjaga bagaimana lembaga pendidikan ini memperoleh kepercayaan dari masyarakat; bagaimana lembaga ini dipercaya oleh masyarakat sebagai tempat untuk menyekolahkan anak-anak mereka. Dan, alhamdulillah, sampai dengan sekarang, masyarakat khususnya di Desa Kalang Semanding masih mempercayai madrasah ini. Salah satu buktinya adalah, jumlah rata-rata peserta didik yang mendaftar di MI Al-Mukminin di setiap tahun pelajaran baru adalah 30 anak. Menurut saya, di tengah ketatnya persaingan dengan lembaga pendidikan dasar lain yang ada di wilayah Desa Kalang Semanding, angka tersebut sudah cukup bagus (Sumali 2019).

Selain menjaga terciptanya Kepercayaan dari masyarakat sekitar, manajemen MI "Al-Mukminin" juga menjaga kepercayaan dari para stake holder. Di antara stake holder dimaksud adalah Kementerian Agama RI yang dalam konteks ini merupakan lembaga negara yang menyalurkan dana Bantuan Operasional Sekolah (BOS) dan dana Bantuan Siswa 
Miskin (BSM). BOS sendiri merupakan bantuan negara yang diperuntukkan antara lain untuk membantu sekolah dalam memenuhi kebutuhan operasional pendidikan, seperti pembelian buku pelajaran yang diperuntukkan bagi seluruh siswa sehingga siswa tidak lagi dibebani biaya untuk membeli buku-buku pelajaran. Sementara itu BSM, sesuai namanya, adalah dana bantuan yang khusus diperuntukkan bagi siswa yang orang tuanya kurang mampu secara ekonomi. Muhayaroh, Bendahara MI "Al-Mukminin" menjelaskan:

Dana BOS dan BSM adalah amanah dari negara yang harus dipertanggungjawabkan. Peruntukan dana tersebut sudah ditentukan oleh negara. Dengan demikian, pihak sekolah benar-benar mengalokasikan dana tersebut dengan penuh tanggung jawab sesuai dengan peruntukannya. Pelaporan penggunaan uang tersebut juga dibuat dan disampaikan kepada pihak-pihak terkait dengan transparan (terbuka).

Kepercayaan yang diberikan oleh stake holder kepada MI "Al-Mukminin", menurut pengamatan penulis, berbanding lurus dengan keberlangsungan lembaga pendidikan tersebut. Hal ini dibuktikan, antara lain, dengan penilaian masyarakat bahwa lembaga tersebut dikelola dengan manajemen akuntabel dan transparan, khususnya dalam hal pengelolaan keuangan. Hasil wawancara penulis dengan dua orang wali murid di bawah ini membuktikan hal tersebut.

Saya sebagai wali murid merasa senang menyekolahkan cucu saya di MI Al-Mukminin, karena madrasah ini memiliki prestasi yang bagus. Selain itu saya juga merasa sangat terbantu dalam membiayai cucu saya bersekolah di MI AlMukminin, karena mendapatkan bantuan untuk siswa miskin. Cucu saya ini sejak bayi tinggal bersama saya, karena ditinggal oleh kedua orang tuanya yang sudah bercerai. Orang tuanya tidak memberikan bantuan biaya, ya biaya hidup ya biaya sekolah. Sudah dua tahun ini cucu saya menerima bantuan itu. Saya lupa namanya bantuan apa, tapi setau saya bantuan itu untuk siswa kurang mampu. (Mutmainnah 2019).

Menurut saya, manajemen MI AlMukminin sudah cukup baik. Meski saya yakin masih ada beberapa hal yang perlu disempurnakan. Tapi paling tidak sampai dengan saat ini, sejauh pengamatan saya sebagai wali murid, madrasah tersebut dikelola dengan baik. Saya belum mendengarkan isu mismanagement yang mencuat ke permukaan. Dana BOS saya kira juga digunakan sesuai dengan peruntukannya. Mohon maaf, saya sebenarnya, insya Allah, cukup mampu untuk sekadar membelikan anak saya buku-buku pelajaran secara mandiri. Tapi karena sekolah menggratiskan biaya buku pelajaran yang berasal dari alokasi sebagian dana BOS, maka menurut saya ini cukup membantu wali murid, bahkan bagi yang mampu sekalipun. Ini juga menunjukkan keseriusan pihak sekolah dalam mengalokasikan dana bantuan 
tersebut secara tepat guna (Wahid 2019).

Hasil wawancara di atas menunjukkan bahwa jika prinsip kepercayaan diterapkan dalam ranah manajemen pendidikan Islam, prinsip tersebut berdampak positif bagi kemajuan suatu lembaga pendidikan Islam. Dampak lainnya adalah terciptanya penilaian positif dari stake holder.

Prinsip terakhir yang diterapkan dalam manajemen pendidikan MI "AlMukminin" Kalangan adalah taqwā (takut kepada Allah). Prinsip ini bahkan secara eksplisit disebutkan dalam visi madrasah yaitu: "Membentuk siswa yang bertaqwa, berilmu, berprestasi dan berbudi pekerti islami”. Dalam kaitannya dengan implementasi prinsip taqwā, Muslih Bashori, Ketua Yayasan Al-Mukminin menjelaskan:

Dalam Islam, takwa merupakan tujuan tertinggi yang hendak dicapai oleh setiap Muslim dalam penghambaannya kepada Allah SWT. Banyak sekali ayat-ayat alQur'an maupun hadis Rasulullah yang menjelaskan keutamaan takwa. Bahkan secara eksplisit al-Qur'an juga menjelaskan keutamaan dan kemuliaan yang akan didapatkan oleh muttaqin atau orang-orang yang takut hanya kepada Allah SWT. Muttaqin akan memperoleh derajat mulia di sisi Allah. Kaitannya dengan ini, Yayasan Al-Mukminin yang menaungi beberapa lembaga pendidikan, termasuk MI AlMukminin, sangat menekankan pentingnya takwa. Takwa bahkan disebutkan paling awal dalam visi madrasah ini. Tentu, tidak hanya siswa yang ingin dibentuk menjadi insan bertakwa, melainkan juga seluruh komponen yang ada, termasuk dan terutama para guru. Karena gurulah yang menjadi agen pencetak sekaligus menjadi contoh nyata bagi para siswa dalam mengamalkan nilai-nilai mulia sesuai ajaran agama Islam, terutama takwa.

Uraian di atas menegaskan bahwa

MI "Al-Mukminin" sangat menjunjung tinggi prinsip takwa. Sebagai lembaga pendidikan Islam, pengelola madrasah ini menyadari bahwa ketakwaan merupakan prinsip tertinggi yang harus disemaikan dalam diri setiap peserta didik. Segala prestasi dan capaian tertinggi yang diperoleh haruslah dibingkai dengan nilai ketakwaan. Di akhir wawancara, Ketua Yayasan AlMukminin bahkan menegaskan: "Prestasi dan kehebatan apapun akan sia-sia jika tidak dilandasi dengan ketakwaan kepada Allah SWT."

\section{KESIMPULAN}

Jika mencermati historisitas madrasah, lembaga pendidikan keagamaan ini tumbuh dan berkembang dari, oleh dan untuk masyarakat Islam, sehingga mereka sebenarnya sudah jauh lebih dahulu menerapkan konsep pendidikan berbasis masyarakat (community-based education). 
Masyarakat, baik secara individu maupun organisasi, membangun madrasah untuk memenuhi kebutuhan pendidikan mereka. Didorong oleh semangat keagamaan dan dakwah disertai dengan manajemen, baik dari segi pendidikan maupun administratif, yang terus menerus dibenahi, madrasah terbukti telah menghasilkan lulusan yang diperhitungkan dan tidak bisa dipandang sebelah mata.

Semangat keagamaan dan dakwah tersebut bahkan pada gilirannya harus berhadapan dengan tuntutan baru terutama menyangkut pemberlakuan Peraturan Pemerintah Nomor 19 tahun 2005 tentang Standar Nasional Pendidikan yang diikuti dengan beberapa Permendiknas sebagai penjabaran dari PP tersebut. Merespons tuntutan tersebut, madrasah—secara gradual namun pasti-berbenah dan menyesuaikan diri. Dalam konteks studi ini, MI "AlMukminin" Kalangan (sebuah madrasah tingkat dasar yang terletak di sebuah desa kecil yang berjarak kurang lebih sepuluh kilo meter sebelah barat Kota Jombang) adalah madrasah yang secara konsisten merespons tuntutan di atas. Perlahan namun pasti madrasah tersebut mencoba memenuhi kriteria minimal tentang sistem pendidikan yang terdiri atas 8 (delapan) standar, yaitu: standar isi, standar proses, standar kompetensi lulusan, standar pendidik \& tenaga kependidikan, standar sarana dan prasarana, standar pengelolaan, standar pembiayaan, dan standar penilaian pendidikan. Pemenuhan standar tersebut merupakan salah satu proses perjalanan panjang madrasah dalam meningkatkan kualitasnya ke standar yang lebih tinggi.

Dari depalan standar di atas, penelitian ini memfokuskan kajian pada "standar pengelolaan" yang peneliti terjemahkan dengan "manajemen". Manajemen tersebut dibingkai dalam prinsip-prinsip manajemen pendidikan dalam Islam. Prinsip-prinsip tersebut meliputi prinsip shürā, prinsip ikhlās, prinsip șidq, prinsip amānah, dan prinsip taqwā. MI “Al-Mukminin” telah menerapkan kelima prinsip tersebut dengan baik. Prinsip-prinsip tersebut diadopsi dan dikolaborasikan dengan prinsip-prinsip manajemen pendidikan pada umumnya. Hal ini bertujuan agar, sebagai lembaga pendidikan Islam, madrasah tidak kehilangan jati dirinya dan pada saat yang sama juga tetap mampu beradaptasi dengan perkembangan zaman dan konstelasi global, khususnya dalam dunia pendidikan, yang terus berkembang pesat. 


\section{REFERENSI}

Abdullah, M. L., \& Syahri, A. (2019). Model of Religious Culture Education and Humanity. Nadwa, 12(2), 331-344. https://doi.org/10.21580/nw.2018.1 2.2 .2756

Ahmad, A. H. (1994). Mukhtar al-Ahadith alNabawiyah. Dar al Fikr.

Alkrdem, M. S., \& Alqahtani, A. S. (2016). Educational Management in the Light of Islamic Standards. Journal of Education, Society and Behavioural Science, $1-9$. https://doi.org/10.9734/BJESBS/2 $016 / 22671$

Al-Qur`an. (2010). Kementerian Agama RI. Dokumen Rencana Kerja Madrasah (RKM) 4 Tabun (2017-2021) MI "AlMukminin" Kalangan Perak Jombang. (2018).

Kartiko, A., \& Azzukhrufi, jaya R. (2019). Pengaruh Budaya Organisasi Dan Kompensasi Terhadap Kinerja Pendidik Di Madrasah Aliyah Nahdlatul Ulama Mazro'atul Ulum Paciran. Nidhomul Haq: Jurnal Manajemen Pendidikan Islam, 4(2), 207-226.

https://doi.org/10.31538/ndh.v4i2. 351
Ma`arif, M. A. (2017). Analisis Konsep Kompetensi Kepribadian Guru PAI menurut Az-Zarnuji. ISTAW A, 2(2), 35-60.

Maarif, M. A., \& Rofiq, M. H. (2018). Pola Pengembangan Kurikulum Pendidikan Pesantren Berkarakter: Studi Implementasi Pendidikan Berkarakter di Pondok Pesantren Nurul Ummah Mojokerto. 13, 16.

Muhammad, A. G. (1991). Kayfa Nata'amal ma'a al-Qur'an. The International Institute of Islamic Thought.

Mukani. (2015). Dinamika pendidikan Islam. Madani.

Ridwan, M. (2018). Konsep Tarbiyah, Ta'lim Dan Ta'dib Dalam Al-Qur'an. Ną̧hruna: Jurnal Pendidikan Islam, 1(1), 35-57. https://doi.org/10.31538/nzh.v1i1. 41

Rosyad, A. M., \& Maarif, M. A. (2020). Paradigma Pendidikan Demokrasi Dan Pendidikan Islam Dalam Menghadapi Tantangan Globalisasi Di Indonesia. Naz̧runa: Jurnal Pendidikan Islam, 3(1), 75-99. https://doi.org/10.31538/nzh.v3i1. 491

Surya, P. (2011). Educational Management: Handbook for School of Education 
Nidhomul Haq, Vol 5 No 1 Tahun 2020

Student. Universita Negeri

Yogyakarta.

http://staff.uny.ac.id/sites/default/f

iles/pendidikan/Priadi\%20Surya, $\% 2$

0S.Pd.,\%20M.Pd./output.pdf

Syamsuddin, A. D. (1994). Al Kabair. Dar al

Fikr.

\section{Wawancara}

Afifah Roziah, Wawancara, Jombang, 20

Januari 2019.

Muflihatun Niswah, Wawancara, Jombang, 20

Januari 2019.

Muhayaroh, Wanacara, Jombang, 20 Januari 2019.

Muslih Bashori, Wawancara, Jombang, 22 Januari 2019.

Mutmainah, Wawancara, Jombang, 27 Januari 2019.

Nur Hidayat Wakhid Udin, Wawancara, Jombang, 27 Januari 2019.

Sumali, Wawancara, Jombang, 20 Januari 2019. 